\title{
Accounting for One Health: Insights from the social sciences
}

Jérôme Michalon*

UMR Triangle - ENS de Lyon site Descartes, Bat D4 (recherche) - 2ème étage, 15 parvis René Descartes, 69342 Lyon cedex 07 - France

Received 31 March 2020, Accepted 21 October 2020, Published online 3 November 2020

\begin{abstract}
This paper discusses the relationship between One Health $(\mathrm{OH})$ and the social sciences. Using a comparison between three narratives of the history of $\mathrm{OH}$, it is argued that $\mathrm{OH}$ can be studied as a social phenomenon. The narrative of $\mathrm{OH}$ by its promoters (folk narratives) emphasizes two dimensions: $\mathrm{OH}$ as a renewal of veterinary medicine and $\mathrm{OH}$ as an institutional response to global health crises. Narratives from empirical social science work explore similar dimensions, but make them more complex. For political sociology, $\mathrm{OH}$ is the result of negotiations between the three international organisations (WHO, OIE and FAO), in a context of a global health crisis, which led to the reconfiguration of their respective mandates and scope of action: $\mathrm{OH}$ is a response to an institutional crisis. For the sociology of science, $\mathrm{OH}$ testifies to the evolution of the profession and veterinary science, enabling it to position itself as a promoter of interdisciplinarity, in a context of convergence between research and policy. In the Discussion section, I propose an approach to $\mathrm{OH}$ as an "epistemic watchword": a concept whose objective is to make several actors work together (watchword), in a particular direction, that of the production of knowledge (epistemic).
\end{abstract}

Key words: One Health, Political Sociology, Science studies, Watchword.

Résumé - Rendre compte de One Health : réflexions issues des sciences sociales. Cet article aborde les rapports entre One Health $(\mathrm{OH}$ - « une santé » en français) et les sciences sociales. L'idée que $\mathrm{OH}$ peut être étudié comme un phénomène social est défendue, au moyen d'une comparaison entre trois narrations de l'histoire de $\mathrm{OH}$. La narration de $\mathrm{OH}$ par ses promoteurs (narrations indigènes) insiste sur deux dimensions : $\mathrm{OH}$ comme renouveau de la médecine vétérinaire et $\mathrm{OH}$ comme réponse institutionnelle à des crises sanitaires. Les narrations issues de travaux empiriques en sciences sociales explorent des dimensions similaires, mais les rendent plus complexes. Pour la sociologie politique, $\mathrm{OH}$ est le résultat d'une négociation entre les trois organisations internationales (OMS, OIE et FAO), dans un contexte de crise sanitaire globale, ayant amené à reconfigurer leurs mandats et leurs périmètres d'action respectifs : $\mathrm{OH}$ est une réponse à une crise institutionnelle. Pour la sociologie des sciences, OH témoigne des évolutions de la profession et de la science vétérinaire, permettant à celle-ci de se placer en position de promotrice de l'interdisciplinarité, dans un contexte de rapprochement entre recherche et action publique. Dans la partie « discussion », je proposerai d'aborder $\mathrm{OH}$ comme un « mot d'ordre épistémique » : un concept dont l'objectif est de faire travailler plusieurs acteurs ensemble (mot d'ordre), dans un sens particulier, celui de la production de savoirs (épistémique).

\section{Introduction: One Health and social sciences}

The purpose of this article is to contribute to reflections on ways to articulate One Health $(\mathrm{OH})$ and social sciences. By "social science", I mean the disciplinary corpus that has developed since the middle of the 19th century, and which deals with the scientific understanding of human behavior, in its relation to institutions. I include in these disciplines: economics, sociology, anthropology, social geography, history, political science and psychology. Unlike philosophy, the social sciences mobilize empirical approaches to answer the questions they ask themselves. In this respect, they can claim the title of "sciences". Being themselves social entities, these disciplines and their contours evolve according to periods and geo-political and institutional contexts. Some social sciences may, for example, approach the life science's epistemology, using laboratory experimental protocols, such as behavioral psychology.

\footnotetext{
*Corresponding author: jerome.michalon@ens-lyon.fr
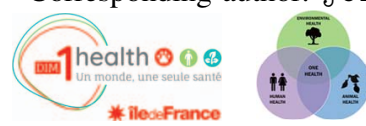

Special Issue - One Health: A social science discussion of a global agenda Invited Editors: Jean Estebanez \& Pascal Boireau
}

This is an Open Access article distributed under the terms of the Creative Commons Attribution License (https://creativecommons.org/licenses/by/4.0), which permits unrestricted use, distribution, and reproduction in any medium, provided the original work is properly cited. 
Conversely, some disciplines of life sciences use methods that are sometimes close to those of the social sciences, such as "field" ethology, for example. But the core of the social sciences can be recognized by its attachment to the ideas of the historicity of human practices, symbolic relationships to others and to the environment, and the construction of institutions and norms that organize collective life. It is this understanding, this vision of the social sciences, that will be discussed in this article, in particular because it is the one most found in the work on $\mathrm{OH}$.

There are two ways in the literature to consider the relationship between $\mathrm{OH}$ and social sciences. The first is to take part in the achievement of the One Health agenda [40]. The aim here is to present the $\mathrm{OH}$ agenda as an opportunity for social sciences: opportunity to promote their skills in producing a general understanding of human behaviour: since changing individual and collective practices is at the heart of the $\mathrm{OH}$ agenda, whose disciplines would be better qualified than social sciences to objectify the social, political, economic and legal processes that can promote or hinder the management of global and transspecific health? In addition to this general knowledge of what humans do, there is also knowledge of the local contexts in which the practices to be changed are observed: How can we ensure that the $\mathrm{OH}$ agenda can be achieved by taking into account practices, knowledge and representations relating to human health, animal health and ecosystem care [64]? On this topic, the expertise of social sciences is presented as crucial (especially that of anthropology, and in particular development anthropology), for the successful deployment of global health, which would not result in the imposition or plating of exogenous norms and practices (by Northern countries) on heterogeneous cultural realities (symbolic and material). The model of "social acceptability" (in its most asymmetrical form) or "co-construction" (in its more egalitarian version) then appears. The role of social sciences would be to ensure compatibility between public policies, technological innovations or development assistance mechanisms and a "target" population that is supposed to receive, accept or co-construct them. In this respect, the $\mathrm{OH}$ agenda presents a very favourable ground for the application of survey methods and co-construction mechanisms, mastered by social sciences and having already proved their worth on other topics [13]. Social sciences therefore propose a dual service offer to the $\mathrm{OH}$ agenda: a cognitive offer, highlighting knowledge of the diversity in practices and representations of human, animal and environmental health; and an operational offer, highlighting knowledge of the processes by which it is possible to arrange this diversity in such a way that it serves the $\mathrm{OH}$ agenda. This operational proposal also applies to the coordination of the actors (politicians, scientists, NGOs) who are supposed to work together within the framework of $\mathrm{OH}$. Here again, social sciences are volunteering to improve the understanding of different institutional and/or disciplinary cultures and to go beyond the logic of "silos" [45]. Generally formulated in purely epistemological terms, the opportunity for social sciences to be included in the $\mathrm{OH}$ agenda is not, however, disconnected from a context of institutional marginality: $\mathrm{OH}$ represents a significant call for financially and epistemologically "dominated" disciplines, in the academic world. The possibility of linking up with multidisciplinary programmes, firmly funded and politically supported at the international level, is not very frequent for social sciences, which might explain their willingness to take an active part in the $\mathrm{OH}$ agenda.

This positioning, this service offer, is not the only way social sciences can grasp $\mathrm{OH}$. A second option is to analyse $\mathrm{OH}$ as an object, as a social phenomenon in itself. This consists in understanding the context in which "One Health" has emerged, which actors promote it, who makes it emerge, and in which networks it circulates, and how it is appropriated by some according to their interests, their strategies, etc. This approach has already proved its worth, and has made it possible to understand the emergence of $\mathrm{OH}$ in the wake of changes in public health management. A large body of literature has focused on $\mathrm{OH}$ as the ultimate avatar of the globalisation mechanisms of human health [26], and animal health [18]. In this trend, a significant number of studies present $\mathrm{OH}$ as a symptom of a new way of managing health risks, making animal health control an opportunity to impose "biosecurity" [20] on a global scale $[16,17,40]$. This descriptive and analytical work shows that the emergence of $\mathrm{OH}$ is linked to varied and complex issues, which are partly beyond the reach of the promoters of the $\mathrm{OH}$ agenda. An overview of $\mathrm{OH}$, its history and ramifications seems difficult to obtain, and the interest of social science work does not lie in the ambition to produce this "meta", "totalizing" point of view on $\mathrm{OH}$. On the contrary, social sciences can be useful to draw attention to some (not all) dimensions that can be obscured by those who think and implement the $\mathrm{OH}$ agenda, notably because of the professional and disciplinary interests that the $\mathrm{OH}$ agenda could help them serve. What does $\mathrm{OH}$ stand for? Who is talking about $\mathrm{OH}$ ? Who speaks in the name of $\mathrm{OH}$ ? Who speaks for $\mathrm{OH}$ ? What does $\mathrm{OH}$ do? What does $\mathrm{OH}$ make actors do? Why $\mathrm{OH}$ now? These dimensions can be quite basic from the point of view of social sciences, but they can be neglected by $\mathrm{OH}$ promoters themselves, even (and perhaps even more) when they intend to report them, and give them meaning. This article aims to show that a social science perspective can enrich the understanding of the emergence of $\mathrm{OH}$, and enrich the point of view of the actors involved in the promotion of $\mathrm{OH}$.

To demonstrate this, I will present three types of narratives of the emergence of $\mathrm{OH}$. First, I will focus on narratives produced by authors explicitly engaged in the $\mathrm{OH}$ agenda (folk narratives), to highlight how they explain "why OH now"? Then, I will present a narrative produced from a political sociology perspective, then another produced from a sociology of science perspective. I will show that these narratives are not necessarily disconnected from each other: although the narratives of the social sciences differ from folk narratives, they take up certain elements of them, providing them with a new perspective.

In the discussion part, I will propose a way to continue the sociological exploration of $\mathrm{OH}$. Noting that the formal dimension of $\mathrm{OH}$ has not yet been taken sufficiently into account to qualify what $\mathrm{OH}$ is, I will propose the notion of "epistemic watchword". 


\section{Materials and methods}

This article is based on the reading and analysis of more than 20 articles, both in social sciences and life sciences. Their common point is to propose, in varying proportions, narratives of the history of $\mathrm{OH}$. Two articles are presented in more detail. They were chosen because there is still little empirical research in the social sciences that traces the origin of $\mathrm{OH}$. They seemed to me to be the most advanced in the application of a sociological approach to the object $\mathrm{OH}$. Moreover, they present two different aspects of this approach: one is based on a qualitative survey, mobilizing interviews with actors who contributed to the fabrication of the $\mathrm{OH}$ concept. The other is based on an in-depth bibliometric survey, which gives access to the evolution of the scientific meanings of the $\mathrm{OH}$ concept. In both cases, an empirical, evidence-based approach is applied. The choice of these papers was therefore not made on the basis of their impact in the field of social sciences interested in $\mathrm{OH}$. Rather, the aim is to present two archetypal models of social science research. Moreover, these two research styles correspond here to two sub-fields of the social sciences: political sociology and sociology of science. The first documents the power relations that exist within and between actors and institutions related to public decision making and politics in general. The second analyzes the social dynamics within and between institutions and actors in the scientific world, and approaches the production of knowledge as a social phenomenon in its own right. Insofar as $\mathrm{OH}$ presents itself as a new way of producing knowledge and governing public health policies, these two articles provide a highly complementary perspective.

This text is more of an essay than a rigorous scientific analysis or a systematic review. Above all, it seeks to identify avenues for reflection on the sociological understanding of $\mathrm{OH}$.

\section{Results}

\section{New bottle or new paradigm? The folk narratives of $\mathrm{OH}$}

Talking about "folk narratives" is a way of indicating that $\mathrm{OH}$ does not develop independently of the stories that are made by the promoters of its genesis. These stories are woven from factual and speculative elements, seeking to account for the emergence of $\mathrm{OH}$ and to give particular guidance to the application of the accompanying agenda. The common point of these stories is that they are produced by authors working in close proximity to the $\mathrm{OH}$ agenda, in finalised research, sometimes within international organisations that promote it. This is what qualifies these stories as indigenous or "folk" and gives their content a particular orientation, both descriptive and strategic.

These narratives thus oscillate between two ways of presenting $\mathrm{OH}$ : either as the new version of a traditional vision of health, which would have been rediscovered; or as a radically new paradigm, appearing in new circumstances, which required innovative responses.

In the first narrative, OH's vision of trans-specific health appears not to be new. Obviously, health care would have at all times required thinking about the interactions between humans, animals and ecosystems. Some authors explain that: "the word HEALTH itself can be interpreted as an acronym composed of: Humans - Ecosystems - Animals - Living Together - Harmoniously." ([14], p. 415). This holistic and systemic dimension may have been forgotten, along the development of scientific human medicine. Only veterinary medicine may have preserved the memory and wisdom of this "global" thought. OH philosophy is said to be at the very heart of veterinary science and practice. $\mathrm{OH}$ could only be "old wine in a new bottle"; the novelty of the thing residing only in the official recognition of the importance of this philosophy carried since always by veterinarians [27, 52]. From such a perspective, making the history of $\mathrm{OH}$ is making the history of veterinarians, and presenting some of them as precursors of $\mathrm{OH}$. Although this narrative is rich in factual elements, the way they are arranged clearly aims at enhancing the value of the veterinary profession, in an exercise of legitimization well analysed by historians [31, 58] and sociologists [6]. Since its creation, the veterinary profession has legitimized itself by emphasizing its indirect contribution to the preservation of human health. In view of the multiplication of narratives discussed here, it can be assumed that $\mathrm{OH}$ provides a new opportunity for the profession to mobilize this rhetoric of interconnection of health processes and centrality of veterinary expertise, to account for and take charge of them. Especially since, as we will see later, veterinarians have already tried to propose integrative concepts, allowing the link between animal and human health (or illness), such as "One Medicine" or even the concept of "zoonosis".

The second folk narrative of OH's genesis is found quite regularly in the Introduction section of articles wishing to implement the $\mathrm{OH}$ approach or presenting results from its application. Unlike the first version, this one insists on the radical novelty that $\mathrm{OH}$ represents. Its appearance can be traced back to the mid-2000s, following a series of global health crises that began in the late 1990s. SARS, the H1N1 virus, but especially the $\mathrm{H} 5 \mathrm{~N} 1$ virus, are presented as major events that have shown the organizational and scientific limitations of the systems of actors in charge of global health management. These emerging diseases, which have fallen under the control of health authorities and international organisations, seem to have overwhelmed their prediction, modelling and coordination capacities. This is what would have pushed these actors to adopt a systemic, holistic framework of thought to deal with the emergence of new health risks. The chronology found in this type of narrative includes the Manhattan Principles (2004), under the aegis of the Wildlife Conservation Society, and their adoption by the American Veterinary Medical Association (AVMA) following the launch of the One Health initiative in 2008, then by WHO, FAO and OIE between 2008 and 2010 (concept note on One World One Health - reiterated in 2017), and by the US Centers for Disease Control and Prevention. In this $\mathrm{OH}$ narrative, a whole series of institutional responses to events requiring a new type of governance and expertise is listed. This "rhetoric of response" is best illustrated by the article by Scoones and Forster [54], which proposes an extensive double entry table in the Appendix, showing in the left column the biological events (disease biology) that occurred between 1997 and 2007, and in the right column the institutional responses (policy responses). As unexpected as pandemics, 
$\mathrm{OH}$ then seems to emerge as a set of new answers to questions that are no less unexpected. This form of narrative, mobilizing a chronological and cumulative perspective (through the succession of strong statements and actions from powerful actors), places $\mathrm{OH}$ in a certain relationship to temporality: $\mathrm{OH}$ is a project that is continually being constituted, each new stage being the opportunity to list new obstacles to its achievement and new challenges to be met. The notion of "project" has been well analysed by sociologists, mostly as a principle of governance and a new tool for managing and controlling behavior [5]. In this narrative, $\mathrm{OH}$ then becomes a horizon that encourages action, an aspect to which I will return later. In addition to the chronological dimension, the mention of certain powerful actors who have adopted $\mathrm{OH}$ (international organisations, certain NGOs and certain professional organisations from powerful States) also gives this narrative an incentive function. Associating $\mathrm{OH}$ with these particular actors (and not others) gives the concept an authority and power to convince anyone of its interest in integrating into the $\mathrm{OH}$ agenda.

OH's folk narratives, whether they insist on the radical novelty of the concept or on its inclusion in the continuity of past practices, have in common to serve the interests of their authors. Such a conclusion will probably come as no surprise to anyone in the world of social sciences. Historians have taught us: writing history is anything but a trivial act. For a long time reserved for the elites, writing history was a tool of power and legitimization of power. OH's stories are no exception. It is therefore interesting to find other narratives, produced by authors whose proximity to the $\mathrm{OH}$ agenda is less significant, who approach the question of power relations between its promoters in a more explicit way.

\section{A response to a governance crisis: $\mathrm{OH}$ as an object for political sociology}

After these stories where $\mathrm{OH}$ appears as an institutional response to events requiring a new form of governance and expertise, let us now turn to a narrative resulting from research in political sociology; in this case, the work of the American sociologist $\mathrm{Yu}-\mathrm{Ju}$ Chien, who published a paper entitled "How did international agencies perceive the avian influenza problem? The adoption and manufacture of the 'One World, One Health' framework". [12] This research consisted in qualitative research, investigating three international organisations (WHO, FAO and OIE), involving interviews with officials of these organisations and also work on archives and grey literature. Chien explains the context in which the $\mathrm{OH}$ concept, despite its vague nature, has been adopted. The health crises of the early 2000s, already mentioned, have indeed generated tension between the three organisations. But unlike the folk narratives, insisting on the organisational limits that health crises brought to light, Chien refers rather to a crisis of legitimacy of the three organisations, in the making for a long time. The spread of H5N1 has led to conflicts over how to limit its impact. The preventive slaughter of poultry to limit contamination is a point of tension between WHO, which advocates the solution as a public health measure, and FAO and OIE, which have in mind the consequences of the measure on livestock farmers and animals. Conflicts of mandate appear as follows: protecting human health (WHO) and preserving animals and economic interests related to animal health (FAO and OIE) contradict each other. It can be added that tensions arise between the OIE and the FAO precisely because each claims expertise and action on animal health protection, with slightly different perspectives (public health for the OIE/livestock and development support for the FAO). On the relationship between the OIE and FAO regarding "animal health" and "zoonosis", see Camille Torres's dissertation [60] and Frédéric Vagneron's work [61]. These inherent tensions in the mandate of these international organisations are exacerbated by a competition for access to the exceptional funds released by some States to respond to H5N1. For example, Canada played a key role in the creation of several coordination bodies between FAO and OIE [60]. In addition to these tensions between international organisations, there are also tensions within these organisations. Between 2003 and 2008, debates emerged on how best to manage public health problems on a global scale, Chien explains. Three "frameworks of public action" are in conflict, indexed to the different types of expertise found in these international organisations (biologists, doctors, veterinarians, economists, epidemiologists, anthropologists, etc.). Biomedical or technical framing - which could also be called "technocratic" consists in defending the application of sanitary measures, coming from institutions (in a top-down logic), and whose legitimacy lies in the recognition of their effectiveness in eliminating viruses and limiting their spread. This is a quasi hunting logic, illustrated by a quote from the first consensus note published by the three organisations: "Find it fast - kill it fast - stop it spreading' (FAO 2008: 13)" cited by Chien ([12], p 217). This biomedical framework is promoted mainly by biomedical experts (human and veterinary medicine). Rather supported by economists and social science researchers, the "societal" or "democratic" framework defends that health problems must be managed collectively, in a bottom-up logic, with the people directly concerned, taking into account the diversity of social contexts and cultural representations, which will make them all the more effective. It is as much a question of ensuring the democratic legitimacy of the measures adopted (an essential element for talking about public policy) as it is of improving their implementation, from a strategic perspective. We find here the elements mentioned in the Introduction, about the positioning of social sciences in relation to $\mathrm{OH}$. Finally, the "environmental" framework emphasizes the need to think about the ecosystemic impacts of ways of managing public health problems, and to always keep in mind the sustainability of the proposed solutions. Led by conservation biology experts, this framework also emphasizes the instrumental dimension of ecosystem concern: depending on whether or not ecosystem functioning is taken into account, the spread of pathogens can be accelerated or curbed. Even though these three frameworks do not have the same institutional weight (biomedical framing is dominant, and the other two are more marginal), they were subject to discussion between 2003 and 2005, and do not help to ensure that the three international organisations present a united front against the challenges of global health and health crisis. The dynamic of collaboration between organisations, supported by some of their Member States, will consist in reducing conflicts between these different frameworks, while 


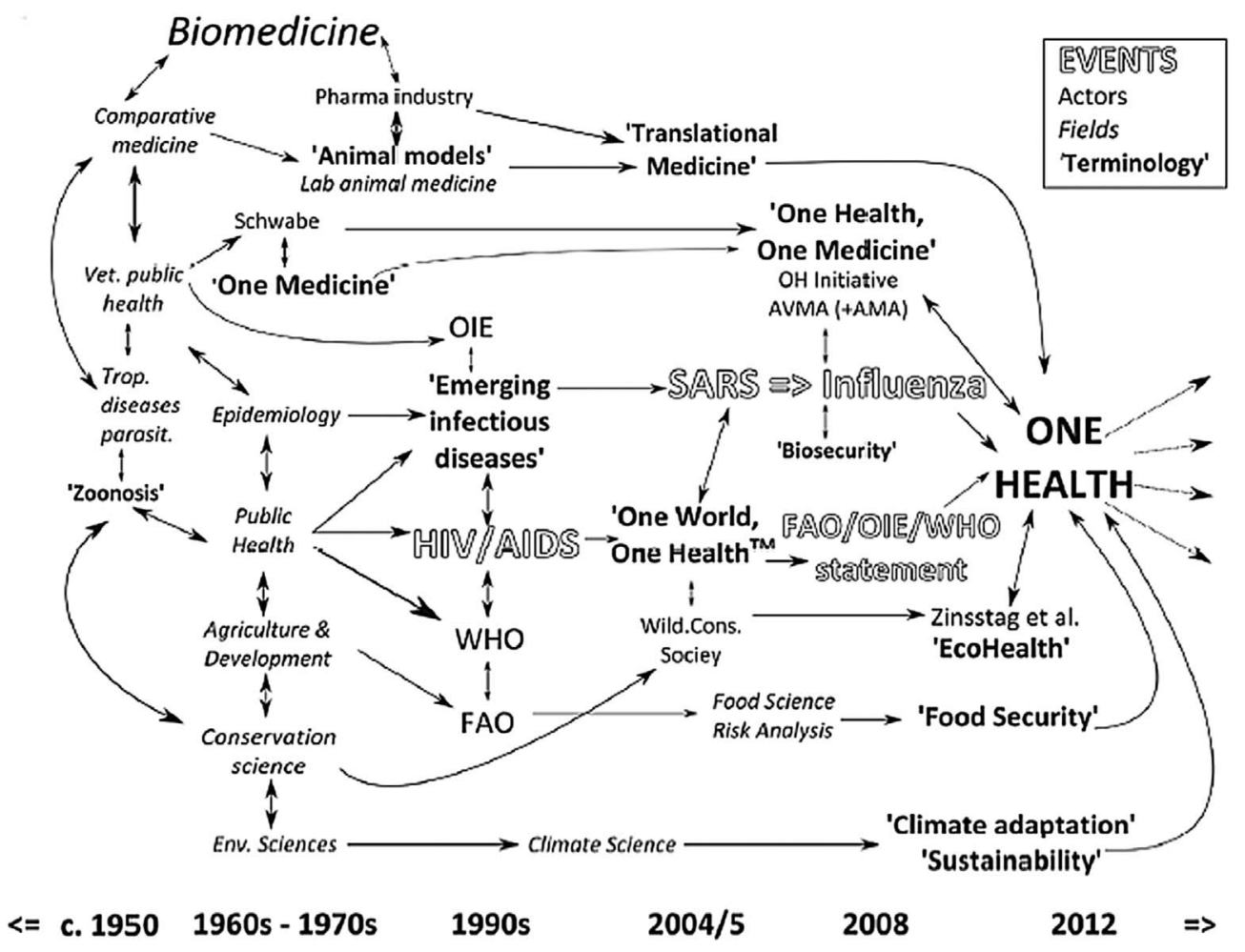

Figure 1. Overview of the One Health history - Cassidy (2016) - p. 226.

respecting the values and expertise that each represents. The publication of the tripartite concept note in 2010 on One World One Health is the result of this effort. $\mathrm{OH}$ emerges here as a new, integrative framework. Its strength lies in the fact that it has managed to reconcile the values of each of the three competing frameworks (modernity - equality - sustainability), and to call for the creation of new knowledge, merging or linking hitherto fragmented areas of expertise. Here, the adoption of $\mathrm{OH}$ is no longer an institutional response to health crises, but more precisely, it is a response to institutional crises generated or revealed by these health crises, in terms of governance and expertise. $\mathrm{OH}$ is thus described by Chien as a tool for pacifying relations between and within international organisations. The success of the operation is based on the "blurry", "vague", "imprecise" nature of the $\mathrm{OH}$ concept, which allows each actor to reformulate its interests, legitimacy and skills as best it can. For each of the actors, $\mathrm{OH}$ provides symbolic legitimacy since it accentuates the common points between the missions of the actors while attenuating their differences: a single health is the objective that all must serve. And $\mathrm{OH}$ provides operational legitimacy since it accentuates the differences between the skills and expertise of the actors and reduces their common points: varied and complementary expertise is necessary to achieve the objective. The $\mathrm{OH}$ agenda will be constituted as the horizon by which these two contradictory dynamics will be articulated. In short, $\mathrm{OH}$ is a tool for pacification because it provides international organisations with a common agenda and recognises that they have complementary skills to carry it out. $\mathrm{OH}$ is therefore approached here as a tool of governance, eminently political. However, a purely institutional reading is not enough. While $\mathrm{OH}$ calls for collaboration between different actors in public health policy, it also encourages the production of a new and innovative form of knowledge. Another narrative of $\mathrm{OH}$, just as relevant as the one just described, would then be to look at the cross-fertilisation of the scientific disciplines invited to work together.

\section{A symptom of science/policy convergence: $\mathrm{OH}$ as an object for sociology of science}

This third narrative is proposed by Angela Cassidy, a sociologist who worked with British historian Abigail Woods as part of a broad research programme to establish the history of $\mathrm{OH}$ in the context of developments in modern medical science [65]. Some of the results of this programme are presented in a chapter of a collective book dedicated to the empirical and critical analysis of interdisciplinary research [11]. This bibliometric and historical study covering the period 1970-2014, leads to a narrative in which OH appears to be the result of long and fluctuating interactions between various scientific disciplines, in particular veterinary medicine, between different ways of conceiving science (epistemic models), and between the academic world and international organisations (Fig. 2).

One of the most interesting results is a synoptic representation of $\mathrm{OH}$ recent history (Fig. 1). It includes both the "events" already mentioned (health crises and statements by international organisations), but also institutional and scientific "actors", "research fields", and, above all, the terminologies that preceded or inspired $\mathrm{OH}$. The relationships between these different "items" are also represented. This scheme is very telling, and reflects the complexity of what led to the adoption 


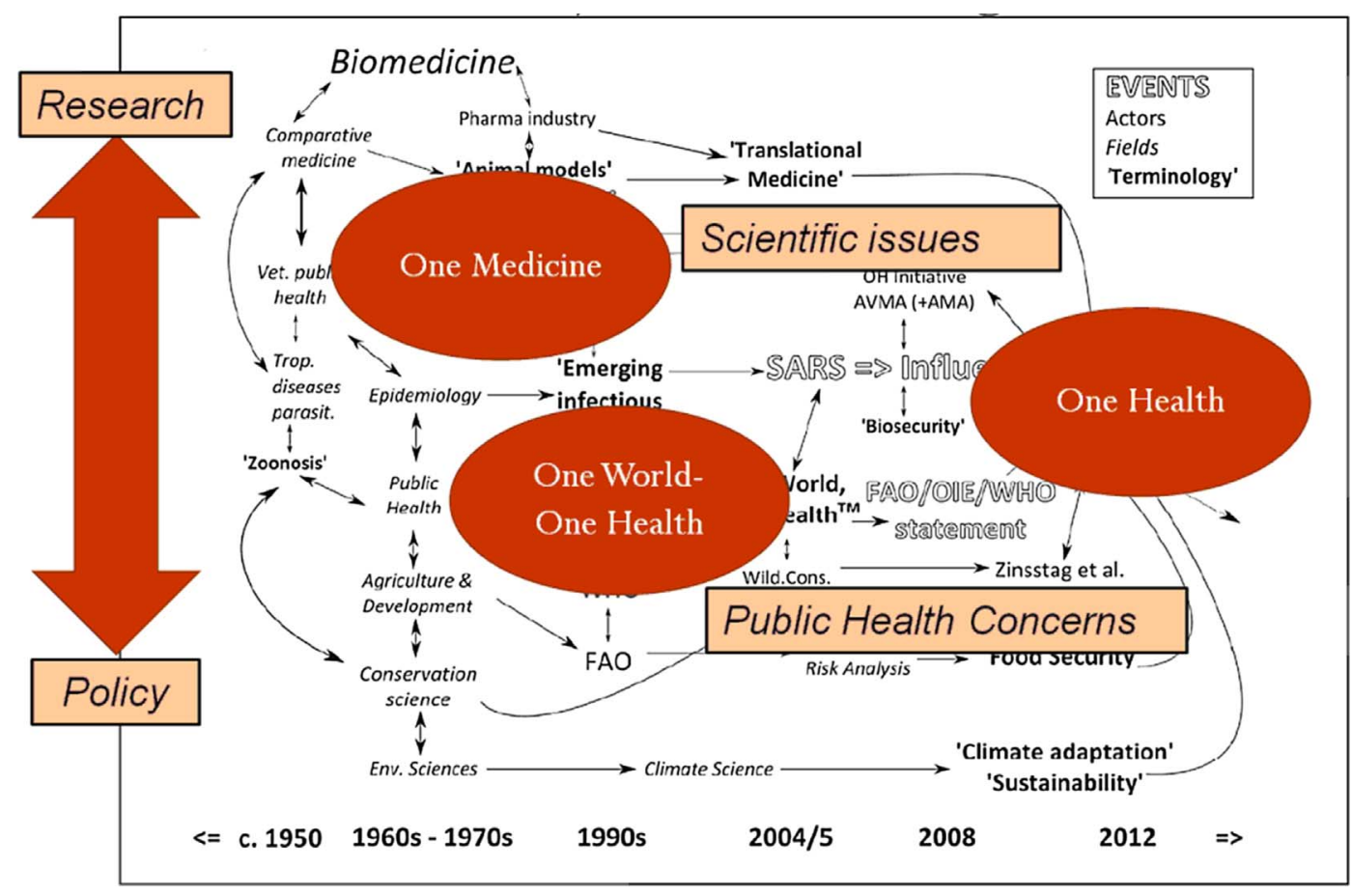

Figure 2. One Health at the meeting point of research and policy - Author - Adapted from Cassidy (2016).

of $\mathrm{OH}$ as a key word recognised by both institutional actors and scientific disciplines. Far from OH's unique genealogies, it can be seen that multiple attempts to promote $\mathrm{OH}$ 's integrative philosophy have been made since the 1950 s, resulting in various conceptual and semantic innovations. The conclusions that can be drawn from this perspective are many. But at the risk of simplifying Cassidy's remarks, I propose to highlight one of them, which is particularly salient. The appearance of $\mathrm{OH}$ in the mid-2000s results from the encounter between two previously developed ways of thinking jointly about human and animal health, corresponding to two terminologies: "One Medicine" and "One World One Health". The One Medicine concept, attached to the name of veterinarian and epidemiologist Calvin Schwabe, is part of the continuity of an old discipline - comparative medicine - and the development of veterinary public health, while maintaining privileged links with research on animal models and translational medicine. In a nutshell, One Medicine gathers actors initially located on the "academic" side and interested in "pure" research questions, without favouring one disease over another: the link between human and animal health represents an epistemic challenge. The concept One World, One Health $(\mathrm{OWOH})$ appears at the crossroads of the field of international relations, in which the concept One World has been used since the 1950s - and the fields of public health and epidemiology, as practiced precisely in international organisations. As already mentioned, management of infectious diseases, from a public policy perspective, is at the heart of the adoption of $\mathrm{OWOH}$. It is important to remember that $\mathrm{OWOH}$ is first and foremost a term coined by the NGO Wildlife Society, which will register the copyright. Between 2004 and 2010, OWOH has been used and discussed by international agencies, which finally transformed it into One Health, for copyright reasons. It is therefore in the world of action (NGO's and international organisations) that $\mathrm{OWOH}$ has mainly circulated. Simplifying again, $\mathrm{OWOH}$ is more in line with an applied science, or "finalised" in the service of public health. Here, the link between human and animal health is first and foremost a public policy issue. In short, $\mathrm{OH}$ is the meeting point between two ways of seeing and practising veterinary science, one more academic, oriented towards research and the other more political or institutional, oriented towards action in general and public action in particular. These are, therefore, also two ways of conceiving the production of knowledge that meet with $\mathrm{OH}$, whose advent also testifies to an intensification of the links between science and public action $[28,34]$, also in the making for several years.

Indeed, since the 1990s, some sociologists have been talking about a global change in the way they think about the production of scientific knowledge [23, 48]. For a long time, they have argued that the scientific world was empowered vis-à-vis the rest of the social world, and it was able to decide for itself how science should be done, its orientations and its institutional organisation. Described as "mode 1" of knowledge production, this situation is gradually being challenged, both for institutional, financial and ideological reasons, considering that science must serve society, and not the other way around. We would thus have switched to "mode 2" of knowledge production, characterised by bringing together the scientific world and extra-scientific actors (industrialists, NGOs, public action), promoting applied and useful research, "context driven", "problem-focused", co-constructed with citizens, interdisciplinary, transdisciplinary or post-disciplinary. Part of the research in sociology of science also points to the need to rethink the division between the natural sciences and the social sciences [33, 41], which is arbitrarily constructed according to a disciplinary logic (instead of an object-centered logic). For these 
sociologists, it is indispensable to reconfigure the relationships between disciplines starting from the objects, and not the other way around. These works thus describe another way of conceiving the production of knowledge, which fits very well with the one promoted by $\mathrm{OH}$ : interdisciplinary and centered on one object (health) supposedly able to overcome the barriers between natural and social sciences. For a critical synthesis of this work, see Shinn [55]. It is then very clear that OH corresponds to this new model of knowledge production, which is widely supported by scientific and academic institutions. The veterinary profession has been able to seize the opportunity of such a context, through the promotion of $\mathrm{OH}$. Cassidy notes the strong investment of the veterinary world in $\mathrm{OH}$, and notes the recurring calls from its stakeholders for interdisciplinary, collaborative research to be produced. Nevertheless, if we look at which publication media have received the most $\mathrm{OH}$-stamped research, the weight of the veterinary discipline is overwhelming: $61 \%$ "One Health" labelled publications are published in veterinary journals. Cassidy even points out that compared to previous terminologies (One Medicine, Comparative medicine, One World One Health), the weight of veterinary medicine has increased in the production of knowledge from an $\mathrm{OH}$ perspective. Finally, the adoption of $\mathrm{OH}$ has positioned veterinary medicine as a leader in interdisciplinary research on public health issues. Thus, the analysis leads us to understand how the promotion of interdisciplinary research can, paradoxically, strengthen the institutional weight of certain disciplines [32].

If $\mathrm{OH}$ 's narrative from a political sociology perspective makes it the product of an institutional crisis, Cassidy's narrative from the sociology of science insists on an institutional transformation: (1) the unprecedented rapprochement between research and policy, scientific institutions and international agencies [22], of which the success of the notion of "evidence based policy" is a sign [42], involving a redistribution of knowledge production capacities (research policies no longer depending solely on the academic world), (2) but also the increased promotion of interdisciplinarity, also leading to a weakening of the weight of certain disciplines, to the benefit of others which present themselves as interdisciplinary by nature.

While the narratives presented here take up some elements of $\mathrm{OH}-\mathrm{OH}$ 's folk narratives as a renewal of veterinary medicine, and/or $\mathrm{OH}$ as an innovation of international public action - the added value of an empirical approach in the social sciences is to escape from a form of reductionism that would consist in having to choose an official version of OH's history. The emergence of $\mathrm{OH}$ is addressed by the social sciences at different scales, behind the scenes of the functioning of international organisations, or in the long term as the institutional contexts in which science and public action are conceived and practiced evolve. It is a whole social context that is depicted, as well as the collective actors who have worked to make $\mathrm{OH}$ a powerful concept, in relation to which a certain number of actors are invited to position themselves. Thus, rather than directly serving the interests of those who write them (and thus giving them power), these narratives, on the contrary, make it possible to better understand where OH's attraction comes from: this power of $\mathrm{OH}$ is explained by the power of the actors who promote it collectively.

\section{Discussion: $\mathrm{OH}$ as an epistemic watchword}

As demonstrated above, the retrospective sociological approaches of the manufacture of $\mathrm{OH}$ are crucial to understand what $\mathrm{OH}$ stands for. However, little has been written so far about the right way to name what $\mathrm{OH}$ is. Again, there are numerous folk terminologies: "Notion", "Concept", "Agenda", "Approach", "Paradigm”, "Slogan", "Umbrella Term”. These concepts are used without justification by the authors, and without the consequences really being drawn from this use. Talking about an agenda or about an approach certainly does not have the same symbolic weight. Here too, a social science approach can be mobilised to help find an appropriate qualifier, adapted to the sociological reality of what $\mathrm{OH}$ is. Let's look at what terms have been proposed by social scientists to describe $\mathrm{OH}$ and others similar concepts.

Chien [12] speaks of $\mathrm{OH}$ as a "framework", thus using the terminology of international agencies, but which clearly reflects the non-binding nature of what $\mathrm{OH}$ is, because some of these organisations have limited normative power over the policies of their Member States, and which, on many subjects, must be content to guide the eyes of national decision-makers, to frame them. For example, on FAO's difficulty in enforcing animal health crisis management principles, beyond just "framing", see Torres [60]. In addition, framework refers to the need for coordination between these organisations, which also implies a certain latitude, which is well reflected in the term "framework". The notion therefore covers the function that $\mathrm{OH}$ promoters intend to give it. Nevertheless, at the end of the investigation, Chien prefers the notion of "boundary-object", because it better reflects what OH's vagueness produces: because $\mathrm{OH}$ is not clearly defined, each actor can project what they want, and appropriate it all the more easily, and to reaffirm the specificity and complementarity of their expertise. In a word, talking about "boundary-object" better reflects what actors $d o$ with $\mathrm{OH}$ among actors: working together and, in the same gesture, reaffirming what makes them different.

Nevertheless, $\mathrm{OH}$ is not an object, it is a word. This specificity seems too important not to be diluted in the vocabulary of the boundary-object, inherited from science studies, which can cover a wide variety of things: technical objects, scientific fields, even institutions [56]. $\mathrm{OH}$ is a word and perhaps there is more to explore about that. As Chien suggests, the formal dimension probably contributed to the adoption of $\mathrm{OH}$ by international organisations: "Most officials at the three agencies recognised that the $\mathrm{OWOH}$ slogan is catchy and appropriate." ([12], p. 219) Precisely, the principles OH covers have been appropriate because $\mathrm{OH}$ is a word and a "good word". What concept should we use to talk about $\mathrm{OH}$, how should we name it taking into account this formal specificity?

Bernadette Bensaude-Vincent [4] proposes the term "buzzwords" to designate concepts such as sustainable development, responsible innovation, personalised medicine, and green technology for example. Like Chien, Bensaude-Vincent indicates that conceptual vagueness plays an important role in the coordination power of these concepts: "As shallow linguistic units deprived of substantial meanings, they create a 'trading zone' that allows different stakeholders to communicate." ([4], p. 250). But for Bensaude-Vincent, this conceptual blur 
is due to the very shape of the buzzword. Like advertising slogans, these buzzwords take their form from marketing and the business world. They are designed to be easily identifiable, distinctive and memorable: catchy. According to BensaudeVincent, the multiplication of these buzzwords in the world of technosciences is as much a sign of the import of economic thought into scientific activity as it is a sign of a change in the scientific world, characterised by an increasing number of scientific institutions, increased internationalisation and competition, as well as a need for coordination to face this competition. In a word: buzzwords are born from the economisation of the scientific universe. From Bensaude-Vincent's analysis, I would like to retain these two dimensions: (1) the indexation of conceptual vagueness on the necessarily synthetic form of buzzwords, and (2) the fact that their purpose is to influence the production of scientific knowledge. These two dimensions plead to approach $\mathrm{OH}$ as a buzzword.

Buzzword has an intuitively depreciative or at least critical connotation: buzzword is associated with impermanence, with something superficial, ephemeral, trendy - a connotation that denies $\mathrm{OH}$ the possibility of constituting a stable political and scientific project. The term "buzz" also suggests that One Health only generates a form of futile agitation, noise. The epistemic dimension would be denied here: the knowledge produced by $\mathrm{OH}$ would, again, only be superficial. For these reasons, talking about $\mathrm{OH}$ as a buzzword is not totally satisfactory. I would like to propose another terminology, another concept: that of "watchword". This notion, which is rather used in the military or political, trade union or activist fields, reflects the fact that $\mathrm{OH}$ is an injunction to collective action, conceived as such, which other terms do not say or in a less obvious way. The notion of watchword explicitly emphasizes OH's strategic and operational dimension: the link with public policies becomes clearer [7]. Moreover, the formal dimension is not neglected here. A watchword is above all a word: like the slogan or the buzzword, the watchword has a particular, synthetic form, which ensures a greater capacity for action.

Indeed, one could simply say that $\mathrm{OH}$ is a watchword because it incites a certain number of actors to manage health problems in a different way. I would like to emphasize another type of action to which $\mathrm{OH}$ encourages: in addition to coordinating actors to work together, it is about producing expert knowledge on the links between human health, animal health and ecosystem conservation. With $\mathrm{OH}$, we are dealing with a particular watchword, a watchword that could be described as epistemic, since it invites several actors to engage in the production of knowledge and reflection. $\mathrm{OH}$ aims at making scientists work together, which justifies calling it an "epistemic watchword". Talking about an epistemic watchword thus makes it possible to account for OH's scientific ancestry, but it also opens up new avenues of research about the current dynamics in the scientific world. While Cassidy's work clearly shows that $\mathrm{OH}$ is the product of the evolution of several scientific disciplines, there is still a need to explore the effects of $\mathrm{OH}$ on other disciplines, and overall on ways of doing science. A first indication of these effects: in a few years, $\mathrm{OH}$ has become a "keyword" of research, used to identify work mobilising integrative, interdisciplinary and holistic approaches to health [15]. From "watchword" to "keyword", the formal dimension of $\mathrm{OH}$ is, again, something worth exploring to account for its power.

There is another reason why I prefer epistemic watchword to buzzword. When we look at how actors engage in the reflection about $\mathrm{OH}$, one of the first tasks they are working on is to clarify the definition of $\mathrm{OH}$. This is the same observation that Chien makes when he describes several conferences dedicated to $\mathrm{OH}$, which begin with the participants' recognition of the extremely vague nature of the concept, and which invariably end with the admission of a failure to develop a more precise definition. "The final consensus of the meeting was that One World, One Health could mean whatever people want to." (Official OIE - interview 2009) ([12], p. 220). In a word, what $\mathrm{OH}$ makes actors do is thinking about what $\mathrm{OH}$ is. We find a rather similar phenomenon in the literature, where several authors question the purely rhetorical or purely semantic dimension of $\mathrm{OH}$ : is $\mathrm{OH}$ something more than a word, a label, an idea? Countless papers provide examples of how the $\mathrm{OH}$ principles have been applied [15], with the aim of proving that $\mathrm{OH}$ is not just a word, and that it is a tangible reality. Other articles critically explore the neglected zones [50] and limits of the $\mathrm{OH}$ agenda [57]. Probably reflecting a form of anxiety about $\mathrm{OH}$ 's potentially incantatory dimension, the existence of these analyses also indicates the reflexivity of scientists who engage in $\mathrm{OH}$ : they too fear that $\mathrm{OH}$ is only a fad, a meaningless institutional injunction, a buzzword. They are working to ensure that this is not the case. This brings back to revisiting Chien's proposition of $\mathrm{OH}$ as a concept whose imprecision is actually very productive. The vagueness of $\mathrm{OH}$ attracts heterogeneous actors and to resolve their possible conflicts. Staying in the blur, in the imprecision, is thus the condition on which these actors can continue to work together. When we look at things in the scientific literature on $\mathrm{OH}$, we realize that researchers are not very comfortable with the blur, and they are working at getting out of the blur, out of the imprecision. Here, it is not the conceptual fuzziness itself that makes actors act, but rather the awareness of this fuzziness, and of the need to overcome it, by giving a more precise outline to $\mathrm{OH}$. The search for precision becomes productive.

Thus, if OH's power lies partly in being promoted by powerful actors, it is also based on its formal qualities (being a particular word), which encourages the mobilisation of the reflective and critical capacities of the individuals to whom it is addressed. The term "epistemic watchword" then seems to me more appropriate to describe a concept like $\mathrm{OH}$ which has the explicit ambition to lead to the production of knowledge and which has the (involuntary?) effect of encouraging its own collective elucidation, even its elicitation.

Acknowledgements. The author would like to thank the two anonymous reviewers for their comments and suggestions; Coralie Martin and Jean Estebanez for the opportunity to present the preliminary results of this research; Amandine Gautier, Sébastien Gardon and Gwenola Le Naour for the discussions, comments and collective work on One Health.

DIM1HEALTH (Région Île de France) is a grant on infectious diseases, which supported research on infectious diseases under the "One Health" prism (www.dim1health.com/). It aims to combine research from various institutional players and to rapidly make the applicable diagnostic, preventive and therapeutic improvements 
(with regard to emerging or re-emerging diseases and sociology developments).

\section{References}

1. Atlani-Duault L, Vidal L. 2013. Le moment de la santé globale. Formes, figures et agendas d'un miroir de l'aide internationale. Revue Tiers Monde, 215(3), 7-16.

2. Barrett MA, Bouley TA. 2015. Need for enhanced environmental representation in the implementation of One Health. Ecohealth, 12, 212-219.

3. Baum SE, Machalaba C, Daszak P, Salerno RH, Karesh WB. 2017. Evaluating One Health: are we demonstrating effectiveness? One Health, 3, 5-10.

4. Bensaude Vincent B. 2014. The politics of buzzwords at the interface of technoscience, market and society: The case of "Public Engagement in Science". Public Understanding of Science, 23(3), 238-253.

5. Boltanski L, Chiapello E. 1999. Le nouvel esprit du capitalisme. Gallimard. pp. 843.

6. Bonnaud L, Fortané N. 2018. L'État sanitaire de la profession vétérinaire. Action publique et régulation de l'activité professionnelle. Sociologie, 9(2018/3), 253-268.

7. Bontems VK. 2014. What does Innovation stand for? Review of watchword in research policies. Journal of Innovation Economics \& Management, 3(15), 39-57.

8. Brown MB. 2015. Politicizing science: Conceptions of politics in science and technology studies. Social Studies of Science, 45(1), 3-30.

9. Bruno I. 2015. Défaire l'arbitraire des faits. De l'art de gouverner (et de résister) par les « données probantes ». Revue Française de Socio-Économie, 2015(2), 213-227.

10. Camus E, Lancelot R. 2008. Les maladies émergentes animales tropicales. Impacts inattendus de l'influenza aviaire. Annales des Mines - Responsabilité et environnement, 51(3), 72-74.

11. Cassidy A. 2016. One Medicine? Advocating (Inter)disciplinarity at the Interfaces of Animal Health, Human Health, and the Environment, in Investigating Interdisciplinary Collaboration: Theory and Practice across Disciplines. Frickel S, Albert M, Prainsack B, Editors. Rutgers University.

12. Chien Y-J. 2013. How did international agencies perceive the avian influenza problem? The adoption and manufacture of the "One World, One Health" framework. Sociology of Health and Illness, 35(2), 213-226.

13. Coffin JL, Monje F, Asiimwe-Karimub G, Janetrix-Amuguni H, Terence O. 2015. A One Health, participatory epidemiology assessment of anthrax (Bacillus anthracis) management in Western Uganda. Social Science \& Medicine, 129, 44-50.

14. Evans B, Leighton F. 2014. A history of One Health. Revue scientifique et technique (International Office of Epizootics), 33(2), 413-420.

15. Falzon LC, Lechner I, Chantziaras I, Collineau L, Courcoul A, Filippitzi M-E, Laukkanen-Ninios R, Peroz C, Pinto Ferreira J, Postma M, Prestmo PG, Phythian CJ, Sarno E, Vanantwerpen G, Vergne T, Grindlay DJC, Brennan ML. 2018. Quantitative outcomes of a one health approach to study global health challenges. EcoHealth, 15(1), 209-227.

16. Figuié M. 2013. Global health risks and cosmopolitisation: From emergence to interference. Sociology of Health and Illness, 35(2), 227-240.

17. Figuié M. 2014. Towards a global governance of risks: International health organisations and the surveillance of emerging infectious diseases. Journal of Risk Research, 17(4), 469-483.
18. Figuié M. 2020. To Be Published: Animal health management: between biosecurity and Global Public Good. Natures, Sciences, Sociétés.

19. Figuié M, Peyre M-I. 2013. Le concept "Une seule santé" : une réponse à l'incertitude dans la gouvernance internationale des zoonoses émergentes ? Revue d'Élevage et de Médecine Vétérinaire des Pays Tropicaux, 66(2), 41-46.

20. Fortané N, Keck F. 2015. How biosecurity reframes animal surveillance. Revue d'anthropologie des connaissances, 9(2), a-1.

21. Frickel S, Moore K, Editors. 2006. The new political sociology of science. Institutions, Networks, and Power, University of Wisconsin Press: Madison. pp. 487.

22. Gardon S, Gautier A, Le Naour G. 2019. La santé globale au prisme de l'analyse des politiques publiques. Santé publique, agronomique et vétérinaire. Éditions de l'École Nationale des Services Vétérinaires-VetAgro Sup: Marcy l'Etoile. pp. 310.

23. Gibbons M, Limoges C, Novotny H, Schwartzman S, Scott P, Trow M. 1994. The new production of knowledge: The dynamics of science and research in contemporary societies. Sage: London. pp. 192.

24. Gibbs EPJ. 2014. The evolution of One Health: A decade of progress and challenges for the future. Veterinary Record, 174 (4), 85-91.

25. Gieryn TF. 1983. Boundary-work and the demarcation of science from non-science: strains and interests in professional ideologies of scientists. American Sociological Review, 48(6), 781-795.

26. Harris J, White A. 2019. The sociology of global health. A literature review. Sociology of Development, 5(1), 9-30.

27. Hendricks J, Newton CD, Rubenstein A. 2009. One medicineone health' at the school of veterinary medicine of the University of Pennsylvania - The First 125 Years. Veterinaria Italiana, 45(1), 183-194.

28. Hess D. 2007. Alternative pathways in science and industry. MIT Press. pp. 344.

29. Hinchliffe S. 2015. More than one world, more than one health: Reconfiguring interspecies health. Social Science \& Medicine, $129,28-35$.

30. Hinchliffe S, Craddock S. 2015. One World One Health? Social science engagements with the one medicine agenda. Social Science \& Medicine, 129, 1-4.

31. Hubscher D. 1999. Les maîtres des bêtes. Les vétérinaires dans la société française (XVIIIe-XXe siècle). Paris: Odile Jacob. pp. 441

32. Jacobs JA, Frickel S. 2009. Interdisciplinarity: A critical assessment. Annual Review of Sociology, 35(1), 43-65.

33. Jasanoff S, Editor. 2004. States of knowledge. The co-production of science and the social order. Routledge: New York. pp. 332.

34. Jasanoff SS. 1990. The fifth branch: Science advisers as policymakers. Harvard University Press: Cambridge. pp. 320.

35. Keck F. 2010. Un monde grippé. Flammarion: Paris. pp. 350.

36. Keck F. 2010. Une sentinelle sanitaire aux frontières du vivant. Les experts de la grippe aviaire à Hong Kong. Terrain, 54, 26-41.

37. Keck F. 2013. Santé animale et santé globale: la grippe aviaire en Asie. Revue Tiers Monde, 215(3), 35-52.

38. Keck F, Mongin O, Padis M-O. 2011. Expertise et choix politique: retour sur la grippe pandémique. Esprit, Mars/avril(3-4), 168-177.

39. Kerouedan D. 2013. Géopolitique de la santé mondiale. Collège de France/Fayard: Paris. pp. 88.

40. Lapinski MK, Funk JA, Moccia LT. 2015. Recommendations for the role of social science research in One Health. Social Science \& Medicine, 129, 51-60.

41. Latour B. 1993. We have never been modern. Harvard University Press. pp. 128. 
42. Laurent C, Baudry J, Berriet-Solliec M, Kirsch M, Perraud D, Tinel B, Trouvé A, Allsopp N, Bonnafous P, Burel F, Carneiro MJ, Giraud C, Labarthe P, Matose F, Ricroch A. 2009. Pourquoi s'intéresser à la notion d' "evidence-based policy" ? Revue Tiers Monde, 4(200), 853-873.

43. Leboeuf A. 2011. Making sense of one health: Cooperating at the human-animal-ecosystem health interface. IFRI Health and Environment Reports, 7, 91.

44. Löwy I. 1992. The strength of loose concepts-boundary concepts, federative experimental strategies and disciplinary growth-the case of immunology. History of Science, 30(90), 371-396.

45. Manlove K, Walker J, Craft M, Huyvaert K, Joseph M, Miller R, Nol P, Patyk K, O'Brien D, Walsh D, Cross P. 2016. "One Health" or three? Publication silos among the One Health disciplines. PLoS Biology, 14(4), e1002448. https://doi.org/ 10.1371/journal.pbio.1002448.

46. Min B, Allen-Scott L, Buntain B. 2013. Transdisciplinary research for complex One Health issues: a scoping review of key concepts. Preventive Veterinary Medicine, 112, 222-229.

47. Murray M, Holmes P, Wright N, Jarrett O., Kennedy P. 2014. History of one health and one medicine. Veterinary Record, 174, 227.

48. Nowotny H, Scott PB, Gibbons MT. 2001. Re-thinking science: Knowledge and the public in an age of uncertainty. Wiley.

49. OIE OMdlSa, Editor. 2017. Bulletin 2017-1: Le bien-être animal, un atout pour l'élevage. Ed. OIE: Paris. pp. 132.

50. Okello AL, Gibbs EPJ, Vandersmissen A, Welburn SC. 2011. One Health and the neglected zoonoses: Turning rhetoric into reality. Veterinary Record, 169(11), 281-285.

51. Osterhaus A, MacKenzie J. 2016. The "One Health" journal: Filling a niche. One Health, 2, 18.

52. Roger F, Caron AC, Morand S, Pedrono M, de GarineWichatitsky M, Chevalier V, Tran A, Gaidet N, Figuié M, de Visscher M-N, Binot A. 2016. One Health and EcoHealth: The same wine in different bottles? Infection, Ecology and Epidemiology, 6(30978). https://doi.org/10.3402/iee.v6.30978.

53. Rüegg S, Buttigieg S, Goutard F, Binot A, Morand S, Thys S, Keune H. 2019. Editorial: Concepts and experiences in framing, integration and evaluation of One Health and EcoHealth. Frontiers in Veterinary Sciences, 6(155). https://doi.org/ 10.3389/fvets.2019.00155.

54. Scoones I, Forster P. 2008. The International Response to Highly Pathogenic Avian Influenza: Science, Policy and
Politics. STEPS Working Paper 10. STEPS Centre: Brighton. https://opendocs.ids.ac.uk/opendocs/handle/20.500.12413/2316.

55. Shinn T. 2002. Nouvelle production du savoir et triple hélice. Tendances du prêt-à-penser les sciences. Actes de la Recherche en Sciences Sociales, 141-142, 21-30.

56. Star LS, Griesemer J. 1989. Institutionnal ecology, "translations", and boundary objects: amateurs and professionals on Berkeley's museum of vertrebate zoology. Social Studies of Science, 19(3), 387-420.

57. Stärk K, Arroyo Kuribrena M, Dauphin G, Vokaty S, Ward M, Wieland B, Lindberg A. 2015. One Health surveillance - More than a buzz word? Preventive Veterinary Medicine, 120(1), $124-130$.

58. Swabe J. 1999. Animals, disease, and human society: Human animal relations and the rise of veterinary medicine. Routledge: London \& New York. pp. 202.

59. Tirado F, Gomez A, Rocamora V. 2014. The global condition of epidemics: Panoramas in A (H1N1) influenza and their consequences for One World One Health programme. Social Science \& Medicine, 129, 113-122.

60. Torres C. 2019. Structuring international public action by the FAO in Animal Health. Example through animal health emergency management and the EMC-AH service. VetagroSup/École Nationale des Services Vétérinaires/IEP de Lyon.

61. Vagneron F. 2015. Surveiller et sunir? Le rôle de l'OMS dans les premières mobilisations internationales autour d'un réservoir animal de la grippe. Revue d'Anthropologie des Connaissances, 9(2), 139-162.

62. Wallace RG, Bergmann L, Kock R, Gilbert M, Hogerwerf L, Wallace R, Holmberg M. 2015. The dawn of Structural One Health: A new science tracking disease emergence along circuits of capital. Social Science \& Medicine, 129, 68-77.

63. Wolf M. 2015. Is there really such a thing as One Health? Thinking about a more than human world from the perspective of cultural anthropology. Social Science \& Medicine, 129, 5-11.

64. Woods A, Bresalier M. 2014. One health, many histories. Veterinary Record, 28, 650-654.

65. Woods A, Bresalier M, Cassidy A, Mason Dentinger R, Timmermann C, Editors. 2018. Animals and the Shaping of Modern Medicine. One Health and its Histories. Timmermann C, Worboys M, Editors. Palgrave McMillan: Manchester. pp. 290.

Cite this article as: Michalon J. 2020. Accounting for One Health: Insights from the social sciences. Parasite 27, 56.

Reviews, articles and short notes may be submitted. Fields include, but are not limited to: general, medical and veterinary parasitology; morphology, including ultrastructure; parasite systematics, including entomology, acarology, helminthology and protistology, and molecular analyses; molecular biology and biochemistry; immunology of parasitic diseases; host-parasite relationships; ecology and life history of parasites; epidemiology; therapeutics; new diagnostic tools.

All papers in Parasite are published in English. Manuscripts should have a broad interest and must not have been published or submitted elsewhere. No limit is imposed on the length of manuscripts.

Parasite (open-access) continues Parasite (print and online editions, 1994-2012) and Annales de Parasitologie Humaine et Comparée (1923-1993) and is the official journal of the Société Française de Parasitologie. 